\title{
Seleksi Fitur Pada Klasifikasi Multi-Label Menggunakan Proportional Feature Rough Selector
}

\author{
Vilat Sasax Mandala Putra Paryoko*1, Arif Djunaidy ${ }^{2}$ \\ ${ }^{1,2}$ Departemen Sistem Informasi, Fakultas Teknologi Elektro dan Informatika Cerdas \\ Institut Teknologi Sepuluh Nopember Surabaya \\ e-mail: *1vilat.19052@mhs.its.ac.id, ${ }^{2}$ adjunaidy@is.its.ac.id
}

\begin{abstract}
Abstrak
Proportional Feature Rough Selector (PFRS) merupakan sebuah metode seleksi fitur yang dikembangkan berdasarkan Rough Set Theory (RST). Pengembangan ini dilakukan dengan merinci pembagian wilayah dalam set data menjadi beberapa bagian penting yaitu lower approximation, upper approximation dan boundary region. PFRS memanfaatkan boundary region untuk menemukan wilayah yang lebih kecil yaitu Member Section (MS) dan Non-Member Section (NMS). Namun PFRS masih hanya digunakan dalam seleksi fitur pada klasifikasi biner dengan tipe data teks. PFRS ini juga dikembangkan tanpa memperhatikan hubungan antar fitur, sehingga PFRS memiliki potensi untuk dikembangkan. Untuk itu, penelitian ini bertujuan untuk melakukan penyesuaian PFRS untuk bisa diterapkan pada klasifikasi multi-label dengan data teks dan bukan teks serta mempertimbangkan korelasi antar fitur. Pengujian dilakukan pada set data publik yaitu 515k Hotel Reviews dan Netflix TV Shows. Pengujian dilakukan dengan menggunakan empat metode klasifikasi yaitu DT, KNN, NB dan SVM. Penelitian ini membandingkan penerapan PFRS pada data multi-label dengan pengembangan PFRS yaitu dengan mempertimbangkan korelasi. Hasil penelitian menunjukkan bahwa penggunaan PFRS berhasil meningkatkan performa klasifikasi. Dengan mempertimbangkan korelasi, PFRS menghasilkan peningkatan akurasi hingga 23,763\%. Pengembangan PFRS juga menunjukkan peningkatan kecepatan yang signifikan pada semua metode klasifikasi sehingga pengembangan PFRS dengan mempertimbangkan korelasi mampu memberikan kontribusi dalam meningkatkan performa klasifikasi.
\end{abstract}

Kata kunci- Klasifikasi Multi-label, Proportional Feature Rough Selector, Data Campuran Teks dan Bukan, Seleksi Fitur

\begin{abstract}
Proportional Feature Rough Selector (PFRS) is a feature selection method developed based on rough set theory (RST). The development is carried out with detailed version of RST. Beside the definition of lower and upper approximation, PFRS dividing the boundary region into two sections called Member Section (MS) and Non-Member Section (NMS). Howerer, the use of PFRS is still limited to binary text classification such as spam filtering and sentiment analysis. In the other hand, PFRS is developed without consideration of each feature's correlation with another feature in dataset. This study aims to make an adaptation of PFRS for multi-label classification, not only for text data, but also another type of data like categorical and numeric data. This study using two public dataset, Netflix TV Shows and Ted Talks. PFRS with correlation is tested using four classic classification method such as DT, KNN, NB and SVM. Results showed that using PFRS in multi-label classification is useful to increase classification performance in each method up to $23,763 \%$. This study also showed that using PFRS with correlation consideration can speed up the classification processes.
\end{abstract}


Keywords - Multi-label Classification, Proportional Feature Rough Selector, Mixed Dataset, Feature Selection

\section{PENDAHULUAN}

$\mathrm{K}$ lasifikasi multi-label merupakan salah satu bentuk proses untuk menganalisis data di berbagai bidang. Beberapa contoh penerapan dari klasifikasi multi-label adalah pengenalan gambar, klasifikasi berita, prediksi kualitas udara hingga identifikasi emotikon pada sosial media [1]. Secara umum, data yang digunakan untuk proses klasifikasi multi-label ini memiliki jumlah fitur atau atribut yang banyak dan fitur-fitur ini mungkin memiliki redudansi dan atau tidak relevan terhadap proses analisa yang akan dilakukan. Hal ini akan menyebabkan permasalahan dalam proses klasifikasi yaitu performa model klasifikasi yang kurang dan menghabiskan banyak sumber daya [2]. Salah satu cara untuk bisa mengatasi hal ini adalah dengan melakukan proses seleksi fitur. Seleksi fitur bertujuan untuk meningkatkan performa klasifikasi dengan memilih sekumpulan fitur yang memiliki peranan penting dalam set data. Selain itu seleksi fitur juga memastikan informasi penting tidak hilang dan menyajikan model yang mudah dianalisis dan diinterpretasikan [3].

Salah satu metode seleksi fitur yang bisa digunakan adalah Rough Set Theory (RST) [4]. RST merupakan sebuah teknik berbasis matematis yang secara efektif mengambil pola-pola penting dari data dan menganalisanya. Teknik ini memberikan keputusan-keputusan penting pada proses seleksi fitur pada data yang tidak konsisten dan tidak lengkap [5]. Beberapa penelitian dilakukan sebagai bentuk pengembangan RST dalam klasifikasi multi-label diantaranya adalah penelitian yang dilakukan oleh Liu et al., yang menggunakan neighborhood rough set yang kemudian dikembangkan khusus untuk klasifikasi teks pada data multi-label [6]. Kemudian penelitian yang dilakukan oleh Li et al., yang mengembangkan fuzzy rough set dengan menggunakan kernel untuk seleksi fitur pada data teks multi-label [2]. Tidak hanya pada data teks, seleksi fitur pada data multi-label juga pernah dilakukan oleh Qian et al., di mana penelitian dilakukan pada lima belas set data berupa teks, gambar dan suara [7]. Dari penelitianpenelitian yang telah disebutkan sebelumnya, data yang digunakan sebagai uji coba merupakan data multi-label dengan satu tipe data, teks atau bukan teks saja sehingga hal ini memberikan ruang untuk pengembangan RST lebih jauh lagi. Satu lagi pengembangan dari RST dilakukan oleh Cekik dan Uysal yaitu Proportional Feature Rough Selector (PFRS) [5]. Pada penelitian ini, RST dikembangkan untuk mengatasi data dengan tingkat redudansi data yang tinggi serta data yang tidak konsisten. PFRS pada penelitian ini hanya digunakan pada klasifikasi teks dalam kelas biner seperti penyaringan spam dan analisis sentimen. Untuk itu, penelitian ini menggunakan PFRS untuk dikembangkan dalam klasifikasi multi-label dengan data tidak hanya teks namun juga dengan data bukan teks sekaligus.

Poin lain yang perlu diperhatikan adalah potensi PFRS untuk bisa dikembangkan dengan memperhatikan korelasi antar fitur. PFRS dikembangkan dengan konsep RST sebagai dasar di mana RST mengelompokkan data secara kasar (rough). PFRS berhasil meningkatkan performa klasifikasi dengan tidak hanya menentukan data yang termasuk pada lower dan upper approximation tapi juga merinci kembali wilayah perbatasan atau boundary region menjadi dua bagian yang lebih kecil yaitu Member Section (MS) dan Non-Member Section (NMS). PFRS tidak mempertimbangkan hubungan antar fitur melainkan hanya mempertimbangkan keberadaan sebuah nilai pada fitur dan label apa yang diberikan pada data tersebut. Sehingga ada potensi yang perlu dikembangkan dari PFRS yakni dengan memperhatikan korelasi antar fitur. Penelitian lain yang dilakukan oleh Dutta et al., menunjukkan bahwa seleksi fitur dengan mempertimbangkan hubungan antar fitur mampu meningkatkan performa klasifikasi [8]. Penelitian lain menyebutkan bahwa pengembangkan seleksi fitur dengan mempertimbangkan

Paryoko, et., al [Seleksi Fitur Pada Klasifikasi Multi-label Menggunakan Proportional Feature Rough Selector] 
ketergantungan antar fitur memberikan hasil fitur optimal yang digunakan dalam proses klasifikasi [3]. Selain itu terdapat penelitian lain yang menerapkan konsep korelasi antar fitur dengan konsep multikolinearitas, di mana adanya dua variabel atau lebih yang memiliki korelasi yang tinggi bisa memberikan data yang redundan [9]. Maka dari itu, penelitian ini bertujuan untuk meningkatkan performa klasifikasi multi-label dengan mengembangkan PFRS dengan mempertimbangkan korelasi antar fitur.

\section{METODE PENELITIAN}

Metode penelitian yang dilakukan memiliki lima tahap seperti yang ditampilkan pada gambar 1. Kelima tahap ini adalah pengumpulan data, praproses data, pengembangan PFRS dengan mempertimbangkan korelasi antar fitur, proses seleksi fitur dan pengujian serta analisis hasil pengujian.

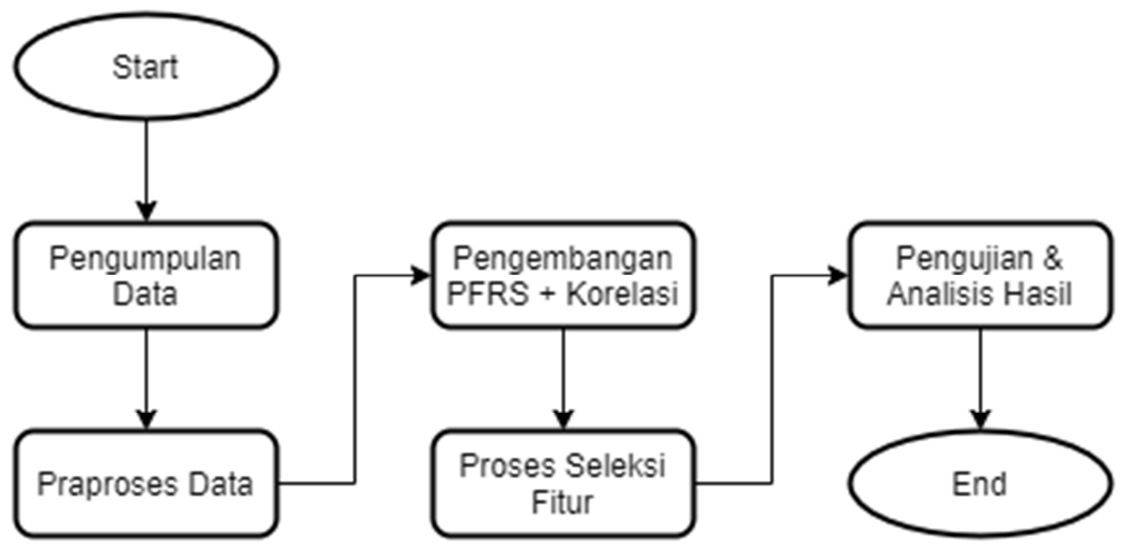

Gambar 1. Metode Penelitian

\subsection{Pengumpulan Data}

Dalam penelitian ini, set data yang digunakan adalah data 515k Hotel Reviews (Hotel Reviews) dan Netflix Movies and TV Shows (Netflix) yang dapat diakses secara publik pada website Kaggle. Data ini memiliki kriteria yang dibutuhkan dalam penelitian yaitu mengandung data berupa teks dan data yang berupa bukan teks yaitu data kategorikal dan numerik. Informasi mengenai set data yang digunakan disajikan pada tabel 1 .

Tabel 1 Informasi Dataset

\begin{tabular}{|c|l|r|r|r|}
\hline No. & Nama Set Data & $\begin{array}{c}\text { Jumlah Data } \\
\text { Setelah Praproses }\end{array}$ & $\begin{array}{c}\text { Jumlah Fitur } \\
\text { Setelah Praproses }\end{array}$ & $\begin{array}{c}\text { Jumlah Label } \\
\text { Setelah Praproses }\end{array}$ \\
\hline 1 & Hotel Reviews & 2.511 & 5.383 & 18 \\
\hline 2 & Netflix & 1.882 & 6.284 & 22 \\
\hline
\end{tabular}

\subsection{Praproses Data}

Praproses data dilakukan berdasarkan tipe atribut data yang akan diproses. Untuk data teks, terdapat enam langkah yang perlu dilakukan dalam praproses data. Diantaranya adalah:

- Melakukan case folding. Proses ini dilakukan untuk menyamaratakan huruf, dalam penelitian ini akan disamaratakan ke huruf kecil.

- Menghapus tanda baca. Hal ini dilakukan untuk menghilangkan karakter lain selain huruf seperti titik (.), koma (,), tanda hubung (-), tanda petik ("') dan sebagainya. 
- Menghapus stopwords. Stopwords merupakan kata-kata yang termasuk sebagai kata depan atau kata penghubung yang tidak memiliki makna berarti.

- Melakukan stemming. Proses stemming dilakukan untuk menghapus berbagai bentuk imbuhan pada kata menjadi bentuk dasar.

- Melakukan lemmatisasi. Lemmatisasi merupakan proses yang dilakukan unutk mengubah bentuk kata menjadi bentuk dasar.

- Melakukan tokenisasi teks hingga menjadi daftar kata. Hal ini dilakukan sebagai upaya menjadikan kata-kata dalam teks menjadi fitur.

Untuk data bukan teks, pada penelitian ini akan diproses berdasarkan apakah data tersebut berupa numerik atau berupa objek. Untuk data integer atau float tidak akan dilakukan praproses. Sedangkan untuk data berupa objek, praproses dilakukan dengan beberapa cara, yaitu:

- Melakukan pengkodean pada nilai data objek dengan mengubahnya menjadi bentuk biner.

- Melakukan penggantian nilai data objek ke dalam bentuk numerik.

\subsection{Pengembangan PFRS dengan Mempertimbangkan Korelasi}

PFRS merupakan pengembangan dari seleksi fitur RST [5]. RST mengelompokkan data menjadi beberapa kelompok. Misalkan U adalah semesta yang berisi objek-objek, kemudian A merupakan sekumpulan atribut fitur dan $\mathrm{C}$ merupakan sekumpulan atribut keputusan. Proses RST diawali dengan mencari relasi yang tidak dapat dibedakan atau indiscernibility. Untuk semua $\mathrm{T} \subseteq \mathrm{A}$, Relasi indiscernibility yang dinotasikan dengan $\mathrm{IND}(\mathrm{T})$, dapat didefinisikan sebagai berikut:

$$
\operatorname{IND}(T)=\left\{\left(x_{i}, x_{j}\right) \in U^{2} \mid \forall a \in T, a\left(x_{i}\right)=a\left(x_{j}\right)\right\}(1)
$$

Konsep utama dari RST adalah penentuan lower approximation dan upper approximation. Dengan kelas kesetaraan dinotasikan dengan $[\mathrm{x}]_{\mathrm{t}}$, untuk setiap $\mathrm{X} \subseteq \mathrm{U}$, didefinisikan sebagai berikut:

$$
\begin{gathered}
\text { Lower }=\left\{x \mid[x]_{T} \subseteq X\right\}(2) \\
\text { Upper }=\left\{x \mid[x]_{T} \cap X \neq \varnothing(3)\right.
\end{gathered}
$$

Dengan mendapatkan kedua tupel ini, maka proses pencarian wilayah perbatasan dan wilayah negatif bisa dilakukan dengan cara:

$$
\begin{gathered}
B N D=\bar{T} X-\underline{T} X(4) \\
N E G=U-U p \operatorname{per}(5)
\end{gathered}
$$

Kemudian PFRS merinci kembali wilayah perbatasan yang dinotasikan dengan BND menjadi dua bagian, yaitu data yang termasuk dalam kelas positif dan data yang tidak termasuk dalam kelas positif. Apabila data termasuk dalam kelas positif, maka data tersebut termasuk dalam wilayah anggota atau Member Section (MS). Sebaliknya, apabila data pada wilayah perbatasan tidak berada pada kelas positif maka data tersebut termasuk dalam wilayah bukan anggota atau Non-Member Section (NMS). Perbedaan konsep dari RST dan PFRS disajikan dengan gambar 2 . 


\section{Jatisi}

ISSN 2407-4322

Vol. 8, No. 4, Desember 2021, Hal. 2084-2094

E- ISSN 2503-2933
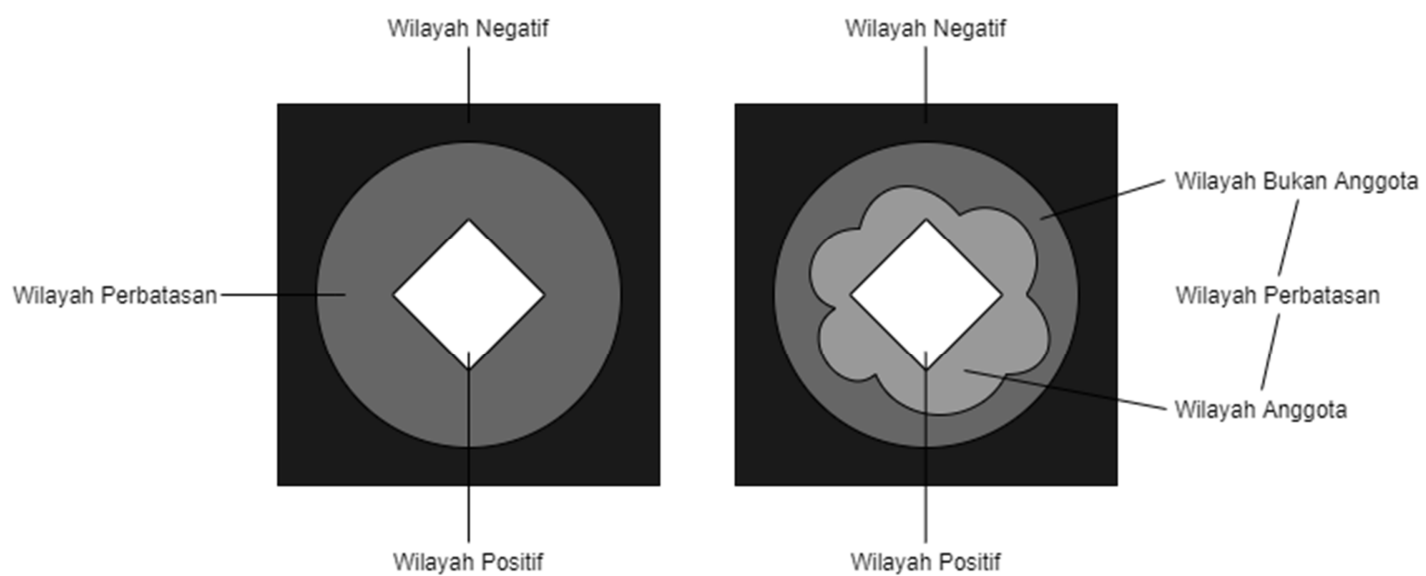

Gambar 2. Perbedaan RST dan PFRS

Penentuan MS dan NMS ditentukan dengan persamaan berikut:

$$
\begin{gathered}
M S=\left\{x \mid x \in B N D \cap C_{i}\right\}(6) \\
N M S=\left\{x \mid x \in B N D \text { and } x \notin C_{i}\right\} \text { and } x \in X_{1}(7)
\end{gathered}
$$

Setelah mendapatkan MS dan NMS, PFRS melakukan evaluasi wilayah perbatasan in dengan sebuah koefisien $\alpha$ untuk digunakan sebagai penentuan nilai penalti pada wilayah perbatasan. Jika jarak jumlah data di MS dan NMS semakin dekat, maka nilai $\alpha$ juga semakin kecil. Nilai ini juga memberikan gambaran mengenai seberapa diskriminasi dari sebuah atribut. Semakin tinggi nilai $\alpha$ maka semakin besar pengaruh atribut tersebut muncul dan mempengaruhi sebuah kelas. Sebaliknya, semakin kecil nilai $\alpha$ maka pengaruh atribut terhadap kelas lain sama-sama besar atau tidak diskriminan. Nilai $\alpha$ ditentukan menggunakan persamaan berikut:

$$
\alpha: U \rightarrow(0,1) \text { and } \alpha=\frac{a b s(|M S|-|N M S|)+1}{|M S|+|N M S|+1}
$$

Kemudian nilai kesenjangan diperlukan untuk menilai ketidakhadiran sebuah atribut dan dikaitkan dengan kelas lain. Nilai kesenjangan ini dinotasikan dengan $\mathrm{SP}_{0} .[\mathrm{x}]_{t=0}$ merupakan data $\mathrm{x}$ di mana fitur $\mathrm{t}$ tidak muncul dalam data. $\mathrm{SP}_{0}$ disajikan dengan persamaan berikut:

$$
S P_{0}=[x]_{t=0}-[x]_{t=0} \cap X_{0}(9)
$$

Dengan mendapatkan semua nilai yang diperlukan, maka nilai PFRS dari atribut t bisa ditentukan dengan persamaan berikut:

$$
\operatorname{PFRS}(t)=\sum_{i=1}^{M} \frac{\mid \text { Lower }|+\alpha *| M S \mid}{|N M S| /\left(\left|S P_{0}\right|+|N E G|+1\right)}(10)
$$

Penentuan korelasi ditentukan dengan menggunakan analisis korelasi Phi Corelation Coefficient (PCC). Setelah mendapatkan nilai PFRS dari masing-masing atribut fitur, maka langkah selanjutnya adalah mendapatkan atribut kondisi yang memiliki korelasi di bawah 0,6 [10]. Nilai korelasi ini diambil karena apabila sebuah atribut memiliki nilai korelasi yang tinggi maka atribut tersebut bisa menyebabkan terjadinya multikolinearitas, di mana sebuah atribut memiliki korelasi atau ketergantungan yang tinggi sehingga berpengaruh pada pembentukan model pada pembelajaran mesin. Dengan adanya dua atau lebih variabel yang memiliki korelasi yang tinggi, maka atribut-atribut tersebut memberikan pengaruh yang sama terhadap penentuan atribut target [11].

Paryoko, et., al [Seleksi Fitur Pada Klasifikasi Multi-label Menggunakan Proportional Feature Rough Selector] 


\subsection{Seleksi Fitur}

Seleksi fitur dilakukan dengan dua skenario. Skenario pertama adalah menggunakan PFRS tanpa mempertimbangkan korelasi antar fitur, skenario kedua seleksi fitur menggunakan PFRS dengan mempertimbangkan korelasi antar fitur. Proses skenario kedua dilakukan dengan melakukan penghapusan atribut-atribut yang memiliki korelasi tertinggi yang melebihi 0,6. Kemudian nilai PFRS dihitung berdasarkan atribut-atribut yang tersisa.

\subsection{Pengujian \& Hasil Analisis}

Pengujian dilakukan dengan membuat model klasifikasi. Model klasifikasi dibuat dengan membagi data latih dan data uji dengan perbandingan 3:2. Metode klasifikasi yang digunakan pada pengujian yakni Decision Tree (DT), $k$-Nearest Neighbor (KNN), Nä̈ve Bayes (NB) dan Support Vector Machine (SVM). Selanjutnya analisis dilakukan berdasarkan akurasi dan waktu proses dari masing-masing metode klasifikasi dengan tiga skenario klasifikasi. Tiga skenario klasifikasi yang dimaksud adalah klasifikasi tanpa menggunakan seleksi fitur, klasifikasi menggunakan seleksi fitur PFRS dan klasifikasi menggunakan seleksi fitur PFRS dengan mempertimbangkan korelasi antar fitur. Masing-masing skenario menggunakan sejumlah fitur bernilai PFRS tertinggi berdasarkan persentasenya yaitu $0,1 \%, 1 \%, 5 \%, 10 \%$, $15 \%, 25 \%$ dan $50 \%$ fitur. Klasifikasi dilakukan menggunakan bahasa pemrogramman python dengan memanfaatkan library MultiOutputClassifier pada sklearn. Parameter untuk masingmasing metode ditentukan dengan melakukan uji coba pada proses klasifikasi. Pada masingmasing metode, parameter apa yang menghasilkan nilai akurasi terbaik, maka parameter tersebut yang akan digunakan sebagai acuan. Tabel 1 menunjukkan nilai parameter untuk masing-masing metode.

Tabel 2. Parameter Metode Klasifikasi

\begin{tabular}{|l|l|}
\hline Metode & \multicolumn{1}{|c|}{ Parameter } \\
\hline DT & Criterion: gini; splitter: random \\
\hline KNN & N_neighbors: $11 ;$ algorithm: auto; weights: distance \\
\hline NB & - \\
\hline SVM & Kernel: $r b f$ \\
\hline
\end{tabular}

\section{HASIL DAN PEMBAHASAN}

Pengujian dilakukan berdasarkan hasil praproses sesuai dengan tabel 1. Seluruh fitur ini merupakan gabungan dari atribut berupa teks dan bukan teks. Kemudian berdasarkan konfigurasi parameter yang telah dijelaskan sebelumnya, didapatkan hasil proses klasifikasi pada set data dengan menggunakan keempat metode tanpa menggunakan seleksi fitur. Hasil ini akan menjadi acuan bagaimana perubahan yang terjadi pada dua skenario klasifikasi lain. Hasil dari klasifikasi tanpa menggunakan seleksi fitur disajikan pada tabel 3.

Tabel 3. Hasil Klasifikasi Tanpa Menggunakan Seleksi Fitur

\begin{tabular}{|c|l|r|r|}
\hline Dataset & Metode & Akurasi (\%) & Waktu (detik) \\
\hline \multirow{4}{*}{ Hotel Reviews } & DT & 79,499 & 7,877 \\
\cline { 2 - 4 } & KNN & 83,977 & 31,166 \\
\cline { 2 - 4 } & NB & 80,380 & 2,094 \\
\cline { 2 - 4 } & SVM & 84,161 & 78,370 \\
\hline \multirow{2}{*}{ Netflix } & DT & 92,448 & 17,149 \\
\cline { 2 - 4 } & KNN & 90,685 & 7,617 \\
\hline
\end{tabular}

Paryoko, et., al [Seleksi Fitur Pada Klasifikasi Multi-label Menggunakan Proportional Feature Rough Selector] 


\begin{tabular}{|l|l|r|r|}
\hline & NB & 91,136 & 2,354 \\
\cline { 2 - 4 } & SVM & 94,060 & 57,391 \\
\hline
\end{tabular}

\subsection{Hasil dan Analisis Klasifikasi Menggunakan PFRS}

Uji coba ini dilakukan dengan membandingkan hasil klasifikasi tanpa menggunakan seleksi fitur dengan klasifikasi dengan menggunakan seleksi fitur. Hal ini bertujuan untuk mengetahui bagaimana pengaruh penggunaan PFRS pada proses klasifikasi berdasarkan akurasi yang didapatkan. Tabel 4 menunjukkan hasil akurasi klasifikasi menggunakan PFRS serta persentase perubahan nilai akurasi yang didapatkan dalam uji coba pengurangan fitur yang digunakan.

Berdasarkan hasil yang didapat, diperoleh adanya perubahan pada penerapan PFRS pada kedua set data. Pada set data Hotel Review, hasil yang didapatkan adalah adanya peningkatan pada klasifikasi KNN sebesar $0,38 \%$ pada penggunaan $10 \%$ dan untuk SVM sebesar $0,21 \%$ pada $5 \%$. Hal ini menunjukkan bahwa seleksi fitur dengan menggunakan PFRS menunjukkan peningkatan nilai akurasi pada penggunaan lebih sedikit fitur. Sedangkan untuk klasifikasi menggunakan DT dan NB menunjukkan adanya pengurangan. Pada klasifikasi DT, penggunaan PFRS terbaik diperoleh pada penggunaan 15\% fitur dengan pengurangan nilai akurasi cukup kecil sebesar $0,08 \%$. Sedangkan untuk klasifikasi NB pengurangan terjadi cukup besar yakni 7,22\% pada penggunaan 50\% fitur. Sedangkan untuk klasifikasi menggunakan set data Netflix, terjadi pula pengurangan dan peningkatan nilai akurasi. Pengurangan terjadi cukup kecil yaitu di bawah $0,5 \%$ yang didapatkan dengan menggunakan klasifikasi SVM dan DT pada penggunaan $50 \%$ fitur sebesar $0,19 \%$ dan $0,45 \%$. Kemudian peningkatan nilai akurasi terjadi pada klasifikasi KNN pada penggunaan $1 \%$ fitur sebesar $0,42 \%$ dan pada NB pada penggunaan $25 \%$ fitur dengan peningkatan sebesar 1,89\%. Dari hasil tabel 4 didapatkan bahwa penggunaan seleksi fitur berhasil meningkatkan nilai akurasi, walaupun terdapat penurunan, penurunan yang terjadi tidaklah signifikan.

Tabel 4. Hasil Klasifikasi Menggunakan PFRS

\begin{tabular}{|c|c|c|c|c|c|c|c|c|c|}
\hline \multirow{2}{*}{ Dataset } & \multirow{2}{*}{ Metode } & \multirow{2}{*}{ Pengukuran } & \multicolumn{7}{|c|}{ Persentase Penggunaan Fitur (\%) } \\
\hline & & & $\mathbf{0 , 1}$ & 1 & 5 & 10 & 15 & 25 & 50 \\
\hline \multirow{8}{*}{$\begin{array}{c}\text { Hotel } \\
\text { Review }\end{array}$} & \multirow{2}{*}{ DT } & Akurasi (\%) & 79,23 & 77,90 & 78,05 & 78,70 & 79,43 & 79,27 & 79,36 \\
\hline & & $\%$ Perubahan & $-0,33$ & $-2,00$ & $-1,81$ & $-0,99$ & $-0,08$ & $-0,28$ & $-0,17$ \\
\hline & \multirow{2}{*}{ KNN } & Akurasi (\%) & 83,77 & 84,08 & 83,94 & 84,30 & 84,24 & 83,98 & 84,14 \\
\hline & & $\%$ Perubahan & $-0,24$ & 0,12 & $-0,03$ & $\mathbf{0 , 3 8}$ & 0,31 & 0,01 & 0,20 \\
\hline & \multirow{2}{*}{ NB } & Akurasi (\%) & 61,31 & 61,71 & 62,42 & 65,11 & 65,62 & 69,40 & $\mathbf{7 4 , 5 7}$ \\
\hline & & $\%$ Perubahan & $-23,72$ & $-23,22$ & $-22,34$ & $-18,98$ & $-18,35$ & $-13,65$ & $-7,22$ \\
\hline & \multirow{2}{*}{ SVM } & Akurasi (\%) & 84,24 & 84,22 & 84,34 & 83,94 & 84,23 & 84,34 & 84,12 \\
\hline & & $\%$ Perubahan & 0,09 & 0,07 & 0,21 & $-0,26$ & 0,08 & 0,21 & $-0,04$ \\
\hline \multirow{8}{*}{ Netflix } & \multirow{2}{*}{ DT } & Akurasi (\%) & 86,57 & 89,84 & 91,74 & 92,15 & 92,02 & 91,86 & 92,27 \\
\hline & & $\%$ Perubahan & $-6,35$ & $-2,82$ & $-0,76$ & $-0,31$ & $-0,45$ & $-0,62$ & $-0,19$ \\
\hline & \multirow{2}{*}{ KNN } & Akurasi (\%) & 90,22 & 91,08 & 90,87 & 90,55 & 90,87 & 90,82 & 90,81 \\
\hline & & $\%$ Perubahan & $-0,50$ & 0,44 & 0,21 & $-0,14$ & 0,20 & 0,15 & 0,13 \\
\hline & \multirow{2}{*}{ NB } & Akurasi (\%) & 88,98 & 91,66 & 92,62 & 92,69 & 92,78 & 92,85 & 92,18 \\
\hline & & $\%$ Perubahan & $-2,36$ & 0,58 & 1,62 & 1,71 & 1,81 & 1,89 & 1,14 \\
\hline & \multirow{2}{*}{ SVM } & Akurasi (\%) & 90,92 & 93,21 & 92,72 & 92,52 & 92,80 & 93,28 & 93,63 \\
\hline & & $\%$ Perubahan & $-3,33$ & $-0,89$ & $-1,41$ & $-1,63$ & $-1,33$ & $-0,82$ & $-0,45$ \\
\hline
\end{tabular}




\subsection{Analisis PFRS dengan Mempertimbangkan Korelasi}

Uji coba ini dilakukan dengan melakukan klasifikasi dengan menggunakan keempat metode pada dua set data yang digunakan. Sebelum menghitung PFRS, dilakukan proses pertimbangan korelasi dengan menggunakan PCC. Kemudian atribut yang memiliki nilai kurang dari 0,6 dihitung nilai PFRS lalu dilakukan klasifikasi seperti yang dilakukan pada uji coba sebelumnya. Kemudian hasilnya dibandingkan dengan penggunaan PFRS tanpa mempertimbangkan korelasi. Hasil dari uji coba ini ditunjukkan pada tabel 5.

Tabel 5 menunjukkan adanya peningkatan pada pertimbangan korelasi dalam penerapan PFRS. Pada set data Hotel Review, pertimbangan korelasi berhasil meningkatkan hasil korelasi pada seluruh metode. Peningkatan tertinggi diperoleh pada klasifikasi menggunakan metode NB dengan peningkatan sebesar $23,76 \%$. Pada set data Netflix, peningkatan terjadi hampir di seluruh metode. Peningkatan terjadi pada metode klasifikasi DT, KNN dan NB. Seadngkan pada klasifikasi SVM menunjukkan adanya penurunan kecil yaitu sebesar 0,5\%. Hasil tersebut menunjukkan bahwa penggunaan PFRS dengan mempertimbangkan korelasi cukup berhasil meningkatan nilai korelasi.

Perbandingan lama proses klasifikasi antara penggunaan seleksi fitur PFRS menggunakan pertimbangan korelasi antar fitur dengan PFRS tanpa mempertimbangkan korelasi antar fitur ditunjukkan dengan grafik. Gambar 3 menunjukkan perbandingan lama waktu proses klasifikasi pada masing-masing metode pada semua dataset. Dari gambar tersebut dapat disimpulkan bahwa dengan mempertimbangkan korelasi PFRS mampu meningkatkan waktu proses klasifikasi.

\section{KESIMPULAN}

Hasil penelitian menunjukkan bahwa menggunakan seleksi fitur PFRS dengan mempertimbangkan korelasi antar fitur memberikan performa lebih baik pada klasifikasi secara keseluruhan. Dari uji coba yang dilakukan, perbandingan pada masing-masing skenario uji coba dapat disimpulkan bahwa peningkatan klasifikasi menggunakan seleksi fitur PFRS dengan mempertimbangkan korelasi berhasil tidak selalu berhasil meningkatkan nilai akurasi, namun peningkatan yang didapatkan hingga mencapai $23,76 \%$ pada klasifikasi menggunakan metode NB. Selain itu seleksi fitur PFRS dengan mempertimbangkan korelasi antar fitur menunjukkan penurunan waktu proses klasifikasi di mana pada keseluruhan uji waktu proses berhasil berkurang. Hal ini menunjukkan bahwa PFRS dengan mempertimbangkan korelasi antar fitur meningkatkan efisiensi klasifikasi.

Tabel 5. Hasil PFRS Dengan Mempertimbangkan Korelasi

\begin{tabular}{|c|c|c|c|c|c|c|c|c|c|c|}
\hline \multirow{2}{*}{ Dataset } & \multirow{2}{*}{ Metode } & \multirow{2}{*}{ Seleksi Fitur } & \multicolumn{8}{|c|}{ Persentase Penggunaan Fitur (\%) } \\
\hline & & & $\mathbf{0 , 1}$ & 1 & 5 & 10 & 15 & 25 & 50 & 100 \\
\hline \multirow{8}{*}{$\begin{array}{l}\text { Hotel } \\
\text { Review }\end{array}$} & \multirow{2}{*}{ DT } & Akurasi (\%) & 78,70 & 79,13 & 78,86 & 79,00 & 78,83 & 79,35 & 79,65 & 79,62 \\
\hline & & $\%$ Perubahan & $-0,67$ & 1,57 & 1,03 & 0,37 & $-0,75$ & 0,09 & 0,37 & 0,16 \\
\hline & \multirow{2}{*}{ KNN } & Akurasi (\%) & 83,97 & 84,50 & 84,51 & 84,36 & 84,42 & 84,45 & 84,24 & 84,51 \\
\hline & & $\%$ Perubahan & 0,24 & 0,50 & 0,67 & 0,07 & 0,21 & 0,55 & 0,11 & 0,64 \\
\hline & \multirow{2}{*}{ NB } & Akurasi (\%) & $\mathbf{7 5 , 8 7}$ & 61,61 & 62,70 & 66,59 & 67,62 & 71,66 & 75,78 & 79,52 \\
\hline & & $\%$ Perubahan & 23,76 & $-0,15$ & 0,44 & 2,26 & 3,04 & 3,26 & 1,62 & $-1,06$ \\
\hline & \multirow{2}{*}{ SVM } & Akurasi (\%) & 84,06 & 84,25 & 84,29 & 84,30 & 84,28 & 84,28 & 84,06 & 84,19 \\
\hline & & $\%$ Perubahan & $-0,21$ & 0,03 & $-0,05$ & 0,43 & 0,06 & $-0,06$ & $-0,07$ & 0,03 \\
\hline \multirow{2}{*}{ Netflix } & \multirow{2}{*}{ DT } & Akurasi (\%) & 89,36 & 89,86 & 88,84 & 88,38 & 88,00 & 90,69 & 91,73 & 92,78 \\
\hline & & $\%$ Perubahan & 3,22 & 0,02 & $-3,15$ & $-4,09$ & $-4,37$ & $-1,27$ & $-0,58$ & 0,36 \\
\hline
\end{tabular}


Jatisi

ISSN 2407-4322

Vol. 8, No. 4, Desember 2021, Hal. 2084-2094

E- ISSN 2503-2933

2092

\begin{tabular}{|l|l|l|r|r|r|r|r|r|r|r|}
\hline \multirow{2}{*}{ KNN } & Akurasi (\%) & 89,09 & 90,10 & 90,05 & 90,26 & 90,45 & $\mathbf{9 1 , 6 4}$ & 91,20 & 90,77 \\
\cline { 3 - 10 } & \% Perubahan & $-1,25$ & $-1,07$ & $-0,90$ & $-0,32$ & $-0,46$ & $\mathbf{0 , 9 0}$ & 0,43 & 0,10 \\
\cline { 2 - 10 } & \multirow{2}{*}{ NB } & Akurasi (\%) & 89,53 & 90,75 & 90,54 & 90,63 & 90,76 & $\mathbf{9 1 , 7 4}$ & 91,60 & 91,59 \\
\cline { 3 - 10 } & \% Perubahan & $\mathbf{0 , 6 2}$ & $-1,00$ & $-2,24$ & $-2,21$ & $-2,17$ & $-1,20$ & $-0,62$ & 0,50 \\
\cline { 2 - 10 } & \multirow{2}{*}{ SVM } & Akurasi (\%) & 89,61 & 91,01 & 90,85 & 91,15 & 91,27 & $\mathbf{9 2 , 8 1}$ & 92,63 & 93,38 \\
\cline { 3 - 10 } & & \% Perubahan & $-1,43$ & $-2,36$ & $-2,01$ & $-1,48$ & $-1,65$ & $\mathbf{- 0 , 5 0}$ & $-1,06$ & $-0,71$ \\
\hline
\end{tabular}

\section{SARAN}

Set data yang digunakan pada penelitian ini adalah set data untuk klasifikasi multi-label dengan tipe data teks dan bukan teks. Metode PFRS memiliki potensi untuk digunakan dalam berbagai jenis data. Untuk teks, pada penelitian ini masih menggunakan teks bahasa Inggris tanpa memperhatikan semantik. Untuk penelitian lebih lanjut, data teks yang digunakan bisa memperhatikan semantik untuk bisa mendapatkan hasil yang lebih baik. 

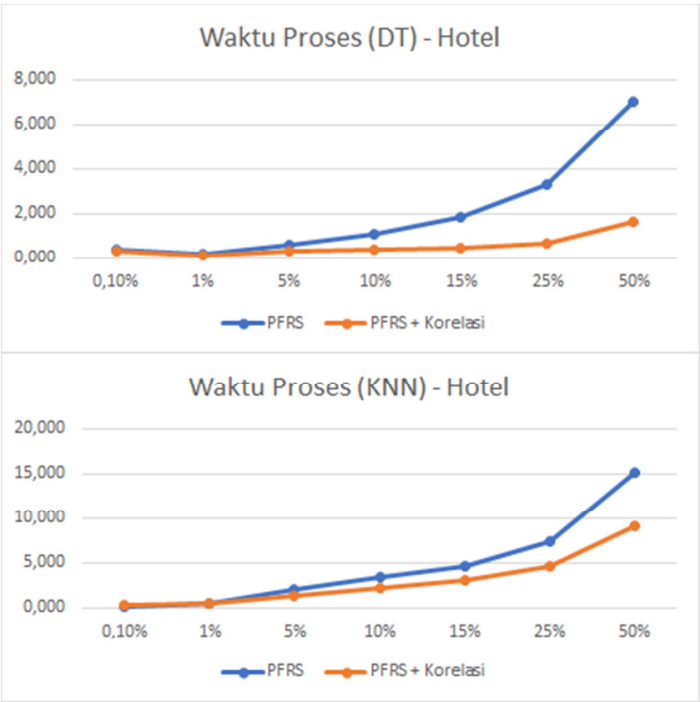

Waktu Proses (NB) - Hotel
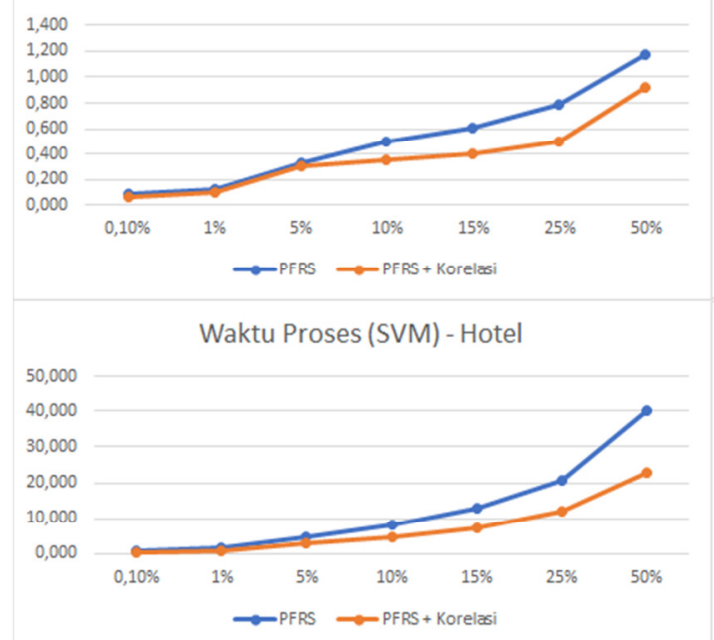

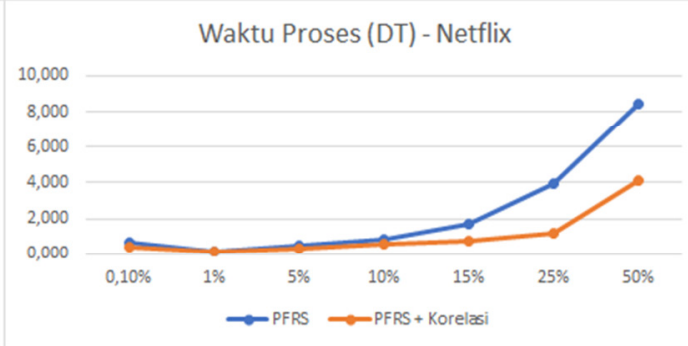

Waktu Proses (KNN) - Netflix

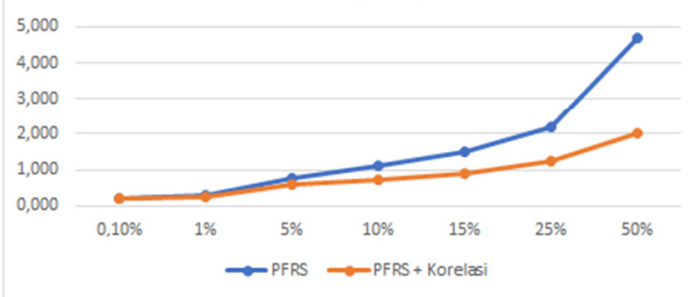

Waktu Proses (NB) - Netflix

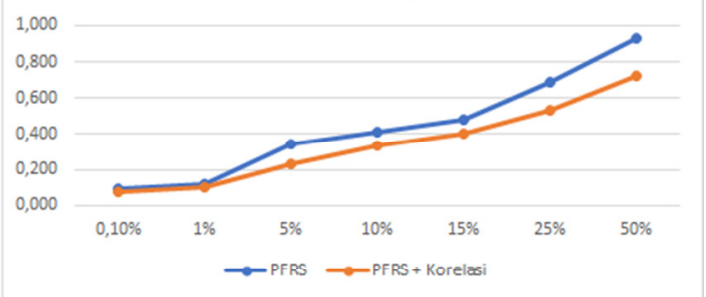

Waktu Proses (SVM) - Netflix

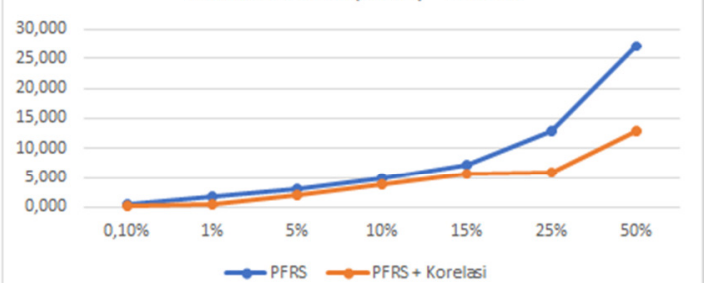

Gambar 3. Perbandingan Waktu Proses Klasifikasi

\section{DAFTAR PUSTAKA}

[1] H. Dong, J. Sun, X. Sun, and R. Ding, 2020, "A Many-Objective Feature Selection For Multi-Label Classification," Knowledge-Based Syst., Vol. 208, p. 106456, doi: 10.1016/j.knosys.2020.106456.

[2] J. Liu, Y. Lin, Y. Li, W. Weng, and S. Wu, 2018, "Online Multi-Label Streaming Feature Selection Based On Neighborhood Rough Set," Pattern Recognit., Vol. 84, pp. 273-287, doi: 10.1016/j.patcog.2018.07.021.

[3] Y. Li, Y. Lin, J. Liu, W. Weng, Z. Shi, and S. Wu, 2018 "Feature Selection For MultiLabel Learning Based On Kernelized Fuzzy Rough Sets,” Neurocomputing, Vol. 318, pp. 271-286, doi: 10.1016/j.neucom.2018.08.065. 
[4] Z. Pawlak, 1982, “Rough Sets,” Int. J. Comput. Inf. Sci., Vol. 11, No. 5, pp. 341-356, , doi: 10.1007/BF01001956.

[5] R. Cekik and A. K. Uysal, 2020, "A Novel Filter Feature Selection Method Using Rough Set For Short Text Data," Expert Syst. Appl., Vol. 160, p. 113691, doi: 10.1016/j.eswa.2020.113691.

[6] J. Liu, Y. Li, W. Weng, J. Zhang, B. Chen, and S. Wu, 2020, "Feature Selection For Multi-Label Learning With Streaming Label," Neuro Computing, Vol. 387, pp. 268-278, doi: 10.1016/j.neucom.2020.01.005.

[7] W. Qian, J. Huang, Y. Wang, and Y. Xie, 2021, "Label Distribution Feature Selection For Multi-Label Classification With Rough Set," Int. J. Approx. Reason., Vol. 128, pp. 32-55, doi: 10.1016/j.ijar.2020.10.002.

[8] S. Dutta, S. Ghatak, R. Dey, A. K. Das, and S. Ghosh, 2018, "Attribute Selection For Improving Spam Classification In Online Social Networks: A Rough Set Theory-Based Approach,” Soc. Netw. Anal. Min., Vol. 8, No. 1, pp. 1-16, , doi: 10.1007/s13278-0170484-8.

[9] A. Senawi, H. L. Wei, and S. A. Billings, 2017, "A New Maximum Relevance-Minimum Multicollinearity (Mrmmc) Method For Feature Selection and Ranking," Pattern Recognit., Vol. 67, pp. 47-61, doi: 10.1016/j.patcog.2017.01.026.

[10] Y. Quintero, D. Ardila, E. Camargo, F. Rivas, and J. Aguilar, 2021, "Machine Learning Models For The Prediction of The SEIRD Variables For The COVID-19 Pandemic Based On A Deep Dependence Analysis of Variables," Comput. Biol. Med., vol. 134, no. March, p. 104500, doi: 10.1016/j.compbiomed.2021.104500.

[11] A. Katrutsa and V. Strijov, 2017, "Comprehensive study of Feature Selection Methods To Solve Multicollinearity Problem According To Evaluation Criteria," Expert Syst. Appl., Vol. 76, pp. 1-11, doi: 10.1016/j.eswa.2017.01.048. 